\title{
Southern Rockies Watershed Project
}

\author{
by Uldis Silins ${ }^{1, *}$, Axel Anderson? 1 , Kevin D. Bladon², Monica B. Emelko ${ }^{3}$, Micheal Stone ${ }^{4}$, \\ Sheena A. Spencer ${ }^{1}$, Chris H.S. Williams ${ }^{1}$, Michael J. Wagner ${ }^{5}$, Amanda M. Martens ${ }^{1}$ and Kirk Hawthorn ${ }^{6}$
}

\begin{abstract}
The Southern Rockies Watershed Project was initiated in 2003 to describe the impacts of severe natural disturbance by wildfire on a broad range of headwaters, larger river basin scale, and downstream water resources (Phase I). This watershed research is unique in that trans-disciplinary linkages between hydrology, biogeochemistry, aquatic ecology, downstream river basin processes, implications for human water use, and economic implications are providing broad insights into wildfire effects on water. A second phase of the research (Phase II) focuses on evaluating the effects of several alternative forest harvesting practices on these same water resource "values". Collectively, this research is providing comprehensive information on watershed function after forest disturbance in Rocky Mountain watersheds.
\end{abstract}

\section{RÉSUMÉ}

Le Projet du bassin hydrographique du Sud des Rocheuses a été lancé en 2003 pour décrire les effets des grandes perturbations naturelles occasionnées par les feux de forêt sur une gamme variée d'eaux d’amont, de bassins versants à grande échelle et de ressources hydriques en aval (Phase 1). Cette étude de bassin versant est unique du fait de ses liens interdisciplinaires entre l'hydrologie, la bio-géochimie, lécologie aquatique, les processus découlement en aval, les implications relatives à l'usage par l'homme de l'eau et leurs conséquences économiques qui permettent d’avoir une perspective globale sur les effets des feux de forêt sur l'eau. Une deuxième phase du projet (Phase II) porte sur lévaluation des effets de diverses techniques d'exploitation alternatives sur les « valeurs » de cette même ressource-eau. Dans son ensemble, cette étude apporte une vaste gamme de renseignements sur la fonction des bassins versants après une perturbation forestière dans les bassins versants des Rocheuses.

\section{Introduction}

The increased occurrence and severity of natural disturbances such as wildfire over the past decade because of shifting climates is well-documented. However the impacts of wildfire on important ecosystem services such as water resources are less well understood. The Southern Rockies Watershed Project (SRWP) was initiated after the 2003 Lost Creek wildfire (21 165 ha; Fig. 1) to document the effects of severe wildfire in Rocky Mountain headwaters regions on a potentially broad range of important watershed functions, including hydrology, water quality, aquatic ecology, and downstream impacts at larger basin scales, including effects on provision of drinking water and drinking water treatment processes (Table 1). Eleven years of post-wildfire watershed research (2004-2014) has produced comprehensive insights into the initial impacts and early trajectory of watershed recovery from both severe wildfire and post-fire salvage harvesting on this broad range of these water resource values. A second phase of the research (Phase II) is investigating comparative impacts of several forest harvesting strategies in a paired watershed study in the same area. Sub-watersheds in one of the two unburned (control) catchments studied since 2004 was logged using each of three alternative harvesting strategies (clear-cut with retention, strip-shelterwood, and partial cut harvesting) with the other unburned watershed serving as a reference catchment. Watershed research focuses on linking six major water themes: hydrology, water quality, stream ecology, regional basin scale effects, downstream implications for municipal drinking water treatment, and economic evaluation of impacts (cost/benefit) to water associated values and ecosystem goods and services. This research is particularly valuable because of the approximately 10 years of pre-disturbance data which are rarely available. Collectively, SRWP phases I and II (Table 2) are providing insights on how the magnitude and longevity of both natural and forest management- associated disturbances affect a broad range of water resources values.

\section{Results}

\section{Hydrology/streamflows}

- Loss of forest canopy after wildfire reduced evaporative losses by interception, and produced deeper snowpacks (Burles and Boon 2011). In the first five years after the fire, net precipitation was $58 \%$ greater during the May-September period. Snowpacks in the burned watersheds were approximately $62 \%$ deeper and contained $80 \%$ greater snow water equivalent than in the unburned watersheds, which would result in greater soil/groundwater recharge and greater runoff in the burned watersheds during spring melt; and,

\footnotetext{
${ }^{1}$ Department of Renewable Resources, University of Alberta, Edmonton, Alberta * corresponding author’s e-mail: uldis.silins@ualberta.ca

${ }^{2}$ Department of Forest Engineering, Resources, and Management, College of Forestry, Oregon State University, Corvallis, Oregon

${ }^{3}$ Department of Civil and Environmental Engineering, University of Waterloo, Waterloo, Ontario

${ }^{4}$ Department of Geography and Environmental Management, University of Waterloo, Waterloo, Ontario

${ }^{5}$ Alberta Agriculture and Forestry, Forest Resource Management Section, Calgary, Alberta

${ }^{6}$ Alberta Agriculture and Forestry, Calgary Forest Area, Forestry Division, Blairmore, Alberta
} 


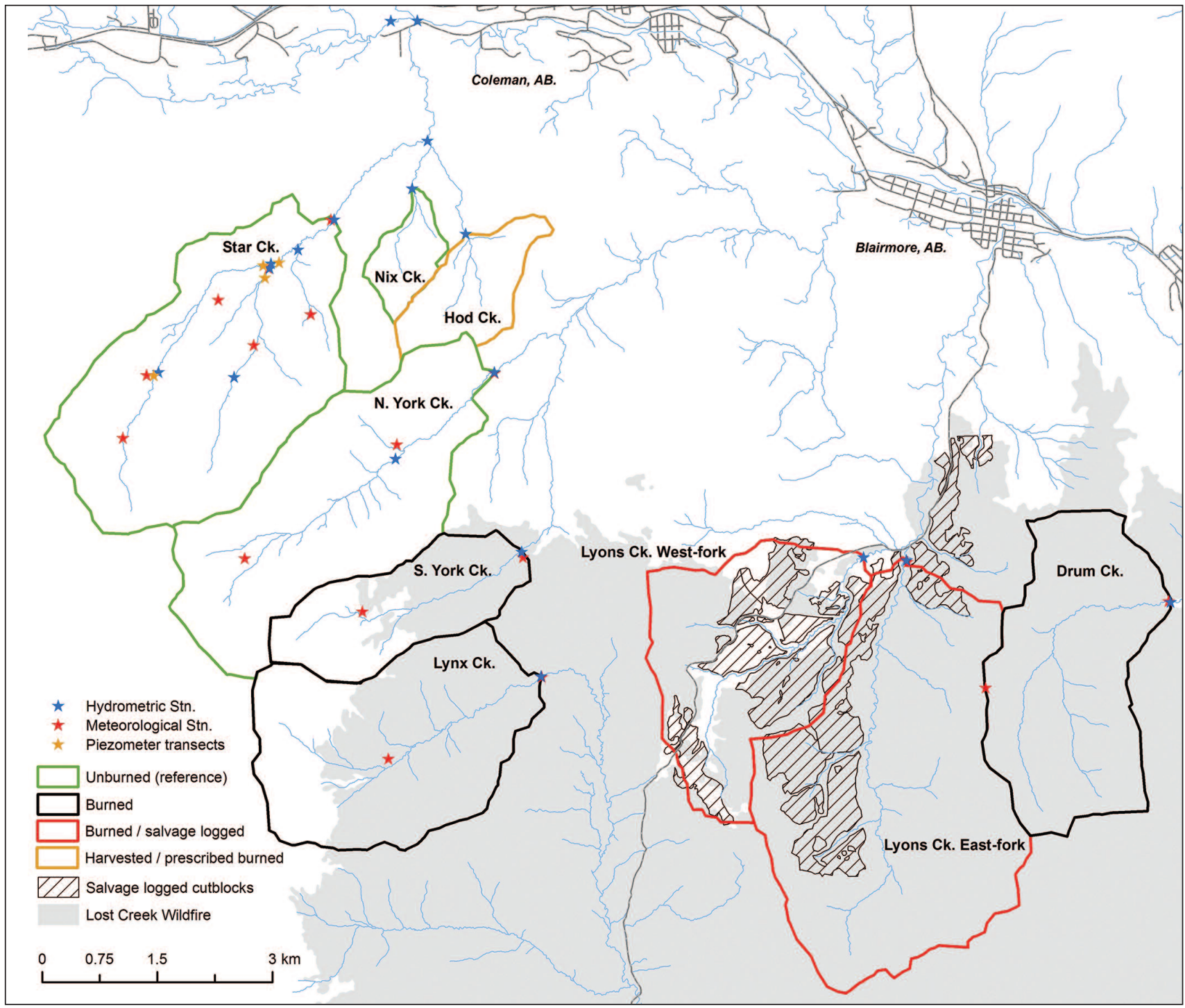

Fig. 1. Southern Rockies Watershed Project - Phase I study watersheds, Crowsnest Pass, Alberta.

- The wildfire did not produce strong effects on streamflows (including peak flows), though earlier onset of spring snowmelt (average $=5$ days) and timing of spring melt freshet flows ( 2.1 days) was evident over the 11-year period since the fire. This is consistent with high resistance and resilience to land disturbance observed by other research teams in high water yielding Rocky Mountain watersheds.

\section{Water quality}

- Nitrogen production was 4-5 times higher in burned and post-fire salvage-logged watersheds in the first year after the fire. It recovered back to levels found in the unburned watersheds within five to six years of the fire (Bladon et al. 2008);

- Phosphorus production was elevated in the burned and salvage-logged watersheds (six and 19 times greater, respectively) compared to the unburned catchments, with no evidence of recovery since the fire 11 years earlier. A large amount of sediment-associated phosphorus has been transported downstream and is stored in stream and river beds which continue to be a source of phosphorus (Allin et al. 2012, Silins et al. 2014);

- Summer stream temperatures were only $1^{\circ} \mathrm{C}-3^{\circ} \mathrm{C}$ warmer in the burned and salvage-logged streams compared to unburned streams despite extensive disturbance to riparian canopies within the burn (MacDonald et al. 2014, Wagner et al. 2014). Stream temperature in this region is more strongly regulated by in-stream upwelling of cold groundwater than by impacts of riparian canopy loss on stream shading,

- Sediment production was elevated in burned and salvagelogged watersheds (nine and 37 times greater, respectively) compared to unburned catchments (Silins et al. 2009). This effect was greatest during spring runoff and spring/summer rainstorms, and has also shown no recovery since the fire; and,

- Trace elements and some metals such as aluminum, man- 
Table 1. Summary of watershed and hydro-climatic setting of SRWP

\begin{tabular}{|c|c|}
\hline & Watershed Location Data \\
\hline Location (descriptive) & $\begin{array}{l}\text { Rocky Mountain front range forest region } \\
\text { in SW Alberta }\end{array}$ \\
\hline Location (geographic) & $49^{\circ} 37^{\prime} \mathrm{N} ; 114^{\circ} 40^{\prime} \mathrm{W}$ \\
\hline Biogeoclimatic zones & $\begin{array}{l}\text { Montane, subalpine, and alpine (domi- } \\
\text { nant tree species: Lodgepole pine, Engel- } \\
\text { mann spruce, and subalpine fir) }\end{array}$ \\
\hline Watershed area & $359-1315$ ha \\
\hline Elevation range & $1432-2635 \mathrm{~m}$ \\
\hline $\begin{array}{l}\text { Precipitation } \\
\text { (mean annual) }\end{array}$ & $800-1360 \mathrm{~mm}$ \\
\hline $\begin{array}{l}\text { Runoff } \\
\text { (mean annual) }\end{array}$ & $610-1225 \mathrm{~mm}$ \\
\hline $\begin{array}{l}\text { Temperature } \\
\text { (mean annual) }\end{array}$ & Jan $-5.3^{\circ} \mathrm{C}$; July $16.4^{\circ} \mathrm{C}$ \\
\hline
\end{tabular}

ganese, cobalt, molybdenum, lead, and nickel were greater in burned and salvage-logged watersheds for five years after the fire. High concentrations of mercury were also evident after the fire in burned and salvage-logged watersheds but declined by the end of summer 2005 .

\section{Aquatic ecology}

- Primary producers (algae) responded dramatically to light, temperature, and nutrient enrichment with thick algal mats on streambeds in the disturbed watersheds (five to seven times greater biomass compared to control watersheds);

- The fire resulted in more invertebrates, a greater number of invertebrate species (richness), shifts in the community structure, and changes in food competition (Silins et al. 2014); and,

- Cutthroat trout (2-3 year-age classes) in the burned watersheds were larger (weight and length) and had higher growth rates (weight and length : age ratios).

\section{Basin scale effects}

- Wildfire changed the properties of sediment (lower settling velocities and higher particle porosities) in wildfireimpacted streams resulting in those sediments remaining in the water column for longer periods and longer downstream transport distances compared to sediments from unburned watersheds;

- Greater sediment-associated phosphorus in settled sediments promoted biofilm production (collimation layers) that stabilized river sediments. However, at higher flows/shear stresses erosion of biostabilized sediments resulted in greater total bed erosion (Stone et al. 2011);

- Sediment source tracing showed that $>80 \%$ of the basinscale sediment that was delivered from the Crowsnest River to the Oldman Reservoir was produced from
Table 2. Research design and variables measured in SRWP Phase I and II

\begin{tabular}{ll}
\hline Research Design \\
\hline Study type & $\begin{array}{l}\text { Phase I: replicated watersheds; Phase II: } \\
\text { nested paired watersheds (BACI; before/after, } \\
\text { control/impact) }\end{array}$
\end{tabular}

Treatments

Phase I: 3 burned watersheds, 2 burned and salvaged logged watersheds, and 1 harvested and prescribe burned watershed; Phase II: 3 alternative harvest treatments (clear-cut w/retention, strip-shelterwood, single-tree and group selection cut) in each of 3 subcatchments

Controls Phase I: 3 unburned watersheds with nested sub-watersheds; Phase II: 1 watershed with nested sub-watershed

Study duration $2004-$ present

Variables measured Discharge, water quality (24 variables; physical-chemical), precipitation, air temperature, solar radiation, wind speed and direction, snow depth and water equivalent, ground water, aquatic ecology (algae, macro-invertebrates, fish)

approximately $14 \%$ of the landscape which was primarily burned by the Lost Creek fire or burned and subsequently salvage- logged (Stone et al. 2014); and,

- Transport and deposition/storage of phosphorus rich sediments long distances downstream of the fire produced long lasting effects on river nutrient levels at larger, regional river basin scales (Emelko et al. 2015).

\section{Water treatment implications}

- The extensive water quality data collected after the Lost Creek wildfire show that dissolved organic carbon (DOC) concentrations of $4-5 \mathrm{mg} / \mathrm{l}$ (near or above which is known to pose additional water treatment challenges) were exceeded in salvage-logged, burned and unburned catchments about $50 \%, 8 \%$, and $4 \%$ of the time, respectively. Turbidity exceeded the 10 NTU threshold about $18 \%$, $10 \%$, and $2 \%$ of the time, respectively (Emelko et al. 2011); and,

- DOC and turbidity are key aspects of water quality that drive drinking water treatment operations and the infrastructure needed to treat source water to produce safe drinking water. Thus, depending on the extent and severity of wildfires and the type of treatment infrastructure in place, wildfires have the potential to generate significant implications for drinking water treatment operations (Bladon et al. 2014).

\section{Management Implications}

Severe wildfires in Rocky Mountain headwaters regions can have wide ranging effects, spanning impacts to hydrology, water quality, and aquatic ecology. These headwaters impacts in turn produce significant downstream effects at larger basin 
scales and demonstrable impacts on drinking water treatability. Strongly differential patterns of recovery from disturbance were observed. Some hydrologic and water quality variables showed little to no initial impact from the wildfire, some variables showed large impacts that recovered to baseline conditions in five to six years while still other variables have shown no evidence of recovery in over a decade since the fire.

\section{References}

Allin, D., M. Stone, U. Silins, M.B. Emelko and A.L. Collins. 2012. The effects of wildfire on sediment-associated phosphorus forms in the Crowsnest River basin, Alberta, IAHS Redbook 354: 1-8.

Bladon, K.D., M.B. Emelko, U. Silins and M. Stone. 2014. Wildfire and the future of water supply. Environ. Sci. Technol. 48: 8936-8943. doi: 10.1021/es500130g.

Bladon, K.D., U. Silins, M.J. Wagner, M. Stone, M.B. Emelko, C.A. Mendoza, K. Devito and S. Boon. 2008. Wildfire and salvage logging impacts on nitrogen export from headwater streams in southern Alberta's Rocky Mountains. Can. J. Forest Res. 38: 2359-2371. doi: 10.1139/X08-071.

Burles K. and Boon S. 2011. Snowmelt energy balance in a burned forest plot, Crowsnest Pass, Alberta, Canada. Hydrol. Process 25: 3012-3029. doi: 10.1002/hyp.8067.

Emelko, M.B., U. Silins, K.D. Bladon and M. Stone. 2011. Implications of land disturbance on drinking water treatability in a changing climate: Demonstrating the need for "source water supply and protection" strategies. Water Res. 45: 461-472. doi: 10.1016/ j.waters.2010.08.051.

Emelko, M.B., M. Stone, U. Silins, D. Allin, A.L. Collins, C.H.S. Williams, A.M. Martens and K.D. Bladon. 2015. Sediment-phosphorus dynamics can shift aquatic ecology and cause downstream legacy effects after wildfire in large river systems [online]. Glob. Change Biol. 22: 1169-1184 doi: 10.1111/gcb.13073.
MacDonald, R.J., S. Boon, J.M. Byrne and U. Silins. 2014. A comparison of surface and subsurface controls on summer temperature in a headwater stream. Hydrol. Process 28: 2338-2347. doi: 10.1002/hyp. 9756.

Silins, U., M. Stone, M.B. Emelko and K.D. Bladon. 2009. Sediment production following severe wildfire and post-fire salvage logging in the Rocky Mountain headwaters of the Oldman River basin, Alberta. Catena 79: 189-197. doi: 10.1016/j.catena.2009.04.001.

Silins, U., K.D. Bladon, E.N. Kelly, E. Esch, J.R. Spence, M. Stone, M.B. Emelko, S. Boon, M.J. Wagner, C.H.S. Williams and I. Tichkowsky. 2014. Five-year legacy of wildfire and salvage logging impacts on nutrient runoff and aquatic plant, invertebrate, and fish productivity. Ecohydrology 7: 1508-1523. doi: 10.1002/eco.1474.

Stone, M., M.B. Emelko, I.G. Droppo and U. Silins. 2011. Biostabilization and erodibility of cohesive sediment deposits in wildfireaffected streams. Water Res. 45: 521-534. doi: 10.1016/j.watres. 2010.09.016.

Stone, M., A.L. Collins, U. Silins, M.B. Emelko and Y.S. Zhang. 2014. The use of composite fingerprints to quantify sediment sources in a wildfire impacted landscape, Alberta, Canada. Sci. Total Environ. 473-474: 642-650. doi: 10.1016/j.scitotenv.2013.12.052.

Wagner, M.J., K.D. Bladon, U. Silins, C.H.S. Williams, A.M. Martens, S. Boon, R.J. MacDonald, M. Stone, M.B. Emelko and A. Anderson. 2014. Catchment-scale stream temperature response to land disturbance by wildfire governed by surface-subsurface energy exchange and atmospheric controls. J. Hydrol. 517: 328-338. doi: 10.1016/j.jhydrol.2014.05.006. 